Preference is given to letters commenting on contributions published recently in the JRSM. They should not exceed 300 words and should be typed double spaced

\section{Effectiveness of cycle helmets and the ethics of legislation}

Replying to criticism of their arguments for compulsory helmet-wearing by cyclists (August $2004 \mathrm{JRSM}^{1}$ ), Dr Cook and colleagues cite 'well-conducted' work from Canada ${ }^{2}$ concerning the effects of helmet-wearing on injury rates. The Canadian study does not in fact attempt this; rather it shows (and compares) injury rates in helmet legislating provinces and non-legislating provinces. Since there is no indication of what effect, if any, the laws had on helmet usage in the jurisdictions covered it cannot be assumed that, when the authorities legislate, helmet-wearing increases. In the province of Ontario, helmet usage was already very high at $65 \%$ among children before the law's implementation. ${ }^{3}$ Since the law has not been enforced, any increase following the law would have been modest_although that would be difficult to verify since no province-wide surveys were conducted after the law came into effect on 1 October 1995.

Also there were contradictions between the Canadian authors' data and their conclusion. Robinson ${ }^{4}$ shows that for the two largest legislating provinces, Ontario and British Columbia (BC), the greatest decreases in head injuries did not occur in the years immediately after respective helmet laws came into effect but rather immediately before. That throws further doubt on the study method.

The absence of enforcement of helmet laws explains the Canadian claim that the number of children riding bicycles does not decrease because of mandatory helmet legislation. ${ }^{5}$ Children seem to know intuitively when a doubtful adult discipline is foisted on them. It did not take long for children in Ontario to figure out that if the cops do not care about helmet laws then why should they. In contrast, British Columbia observed increases in helmet use following legislation, ${ }^{6}$ but that was coincident with aggressive enforcement and ticketing campaigns by local police (Personal communications with BC cyclists). The BC government did not feel the issue important enough to organize pre-law and post-law surveys to gauge the impact of its law on cycling levels. However, a 35\% reduction in all reportable cycling accidents between the two complete years immediately before and after the law's enforcement, 1995 and 1997,7 suggests considerable declines in cycling. Interestingly, head injuries in $\mathrm{BC}$ declined at a slower rate than the number of cycling accidents.

Helmet campaigners uncritically latch on to any claim to push helmet agendas. Campaigners in the $\mathrm{UK}^{8}$ have already used the Canadian work in support of their arguments for legislation, including a claim that mandatory helmet legislation in Canada saved lives. The authors did not respond to my requests for substantiation of the latter claim; it may have originated from non-significant differences in the fatality data of Macpherson et al. ${ }^{2}$ An analysis of 28 years of Transport Canada's traffic fatality data ${ }^{9}$ shows that the fatality trend for cyclists is virtually identical to the one for pedestrians. Thus it seems that other factors account for declining fatality and injury trends.

Dubious claims on the efficacy of helmet legislation threaten the life-extending benefits of cycling and the gains being made from exercise in reducing heart disease, cancer and obesity.

\section{Avery Burdett}

313L St Patrick Street, Ottawa, Ontario, Canada K1N 5K6

E-mail: avery@magma.ca

\section{REFERENCES}

1 Cook A, Ashcroft R, Sheikh A. Effectiveness of cycle helmets and the ethics of legislation. $J$ R Soc Med 2004;97:410-11

2 Macpherson AK, To TM, Macarthur C, Chipman ML, Wright JG, Parkin PC. Impact of mandatory helmet legislation on bicycle-related head injuries in children: a population-based study. Pediatrics 2002;110:e60

3 Statistics Canada: factors associated with bicycle helmet use. Health Reports 1997;9:no. 2

4 Robinson DL. Confusing trends with the effect of helmet laws [http:// pediatrics.aapublications.org/cgi/eletters/110/5/e60]

5 Macpherson AK, To TM, Parkin PC. Mandatory helmet legislation and children's exposure to cycling. Inj Prev 2001;7:228-30

6 Highway Safety Research Center. Effects of the helmet use law in British Columbia [http://www.hsrc.unc.edu/pubinfo/bike_bchelmets.htm]

7 Insurance Corporation of British Columbia. Traffic collision statistics [http://www.icbc.com/Library/research_papers/Traffic/index.html]

8 Lee AJ, Mann NP. Cycle helmets. Arch Dis Child 2003;88:465-6

9 The Vehicular Cyclist. Helmet effect undetectable in fatality trends [http://www.magma.ca/ ocbc/fatals.html]

\section{Neurorehabilitation}

The definitions and care pathways proposed by Professor Pickard and colleagues (August $2004 J R S M^{1}$ ) are clearly useful and we applaud their efforts. May we recommend our model for neurorehabilitation services in Greater Manchester as a practical method to establish an organized and equitable head injury service within the context of a comprehensive neurorehabilitation structure.

Greater Manchester, with a population of 2.5 million, has a regional neuroscience unit based at Hope Hospital, Salford. The need for neurorehabilitation services within neuroscience was addressed by establishing an acute rehabilitation unit (ARU) at Hope Hospital to admit people directly from the neurosurgical and acute neurology wards for acute-phase rehabilitation at a time when they may still be medically unstable. Once patients are neurologically stable, they can be transferred to one of four intermediate rehabilitation units (IRUs) located at Wigan, Stockport and 
Rochdale and in central Manchester. The ARU and IRUs provide interdisciplinary, equitable, and cost-effective rehabilitation services for people with head injury and other disabling neurological disorders. All the units function as a service network regarding issues such as clinical governance, outcome measures and lobbying for resources. Despite the persistence of inequalities in access to some aspects of community rehabilitation and in transfer waiting times, we feel that the model helped greatly in provision for Greater Manchester residents irrespective of postcode.

Tarek A-Z K Gaber

Michael U Eshiett

Leigh Infirmary, Greater Manchester WN7 1HS, UK

\section{REFERENCE}

1 Pickard JD, Seeley HM, Kirker S, et al. Mapping rehabilitation resources for head injury. J R Soc Med 2004;97:384-9

\section{Intestinal obstruction due to malrotation}

Mr Awan and his colleagues (July $2004 J R S M^{1}$ ) report a case of malrotation in an adult. As they point out, this condition is much more often encountered in childhood. Paediatric surgeons would not agree that the operation done in this case, with an attempt to restore normal anatomy, was the correct one. The standard operative procedure is based on that described by Ladd 70 years ago- detorsion of the volvulus, division of adhesions, broadening of the smallbowel mesentery and positioning of the duodenum down the right side of the abdomen and the caecum into the left iliac fossa. There was a brief vogue in the 1960s for stabilization, as performed by Awan and colleagues, but this was never accepted by the paediatric surgical community; indeed a study by Shier et al. ${ }^{2}$ in 1987 confirmed that it has a higher morbidity than the Ladd procedure.

\section{Richard D Spicer}

Department of Paediatric Surgery, Bristol Royal Hospital for Children, Bristol BS2 8BJ, UK

\section{REFERENCES}

1 Awan AK, Macafee DAL, Hall RI. Intestinal obstruction in an adult with Down's syndrome. J R Soc Med 2004;97:334-5

2 Schier F, Schafer W, Waldschmidt J. Zur chiurgischen Therapie dee malrotation in Kindesalter. Z Kinderchir 1987;45:215-18

\section{Authors' response}

As non-paediatric surgeons dealing with an adult, we took a pragmatic approach to an emergency situation. Placing the caecum in the left iliac fossa was not an option, since it had been removed, and the intestines were placed in the position in which they lay most easily.

\section{Ataf K Awan ${ }^{1}$}

Richard I Hall ${ }^{2}$

\section{Assessment of surgeons in the workplace}

I welcome many of the ideas set out by Professor Rowley in his editorial (August $2004 J R S M^{1}$ ). Clearly, assessment in the workplace is the way forward. But where does the patient come in all this? Will patients be told that a junior surgeon will be performing their operation and that a more senior one will be assessing them as they do it? Surely these assessments should not be done until the patient has given explicit and informed consent. In one study only $38 \%$ of teaching hospitals in the United States informed patients that students would be involved in their care. ${ }^{2}$ Do we do any better when junior surgeons are involved?

Some people may argue that society as a whole will benefit as a result of better assessment of surgical skills. But it should be up to the patient as an individual to decide whether or not to contribute to society in this way. How would we feel if it was a member of our own family? A study by Diekema et al. ${ }^{3}$ showed that children of doctors were less likely to see trainees than other children attending an emergency department.

\section{Kieran Walsh}

8 Elmhurst Villas, Cheltenham Road, London SE15 3AE, UK E-mail:kmwalsh@bmjgroup.com

\section{REFERENCES}

1 Rowley DI. The surgeon's job: how should we assess the trainee? J R Soc Med 2004;97:363-5

2 Cohen DL, McCullough LB, Kessel RW, Apostolides AY, Alden ER, Heiderich KJ. Informed consent policies governing medical students' interactions with patients. J Med Educ 1987;62:789-98

3 Diekema DS, Cummings P, Quan L. Physicians' children are treated differently in the emergency department. Am J Emerg Med 1996;14:6-9

\section{Research capacity in complementary medicine}

A report by the House of Lords in 2000 suggested that the dearth of research capacity in complementary medicine (CM) should be remedied by creation of centres of excellence. ${ }^{1}$ The UK Department of Health, however, decided on a different strategy and currently funds 9 isolated postdoctorate fellowships at various UK institutions of higher education, each supervising one PhD student. The costs of this exercise are about $£ 2$ million. For roughly the same amount of money, my unit has during the past eleven years hosted 33 researchers (this figure excludes my current staff). Of those who came and left, 17 were from the UK, 2 each from Germany, Japan, Korea and Sri Lanka, the rest from other countries. 17 held paid employment while the rest had honorary positions. 26 researchers continued CM research after leaving my unit. An independent analysis has suggested that my unit is the most productive research centre of CM in the world. ${ }^{2}$ These data, I believe, indicate 
that sponsorship of centres of excellence is the most effective way to generate research capacity in CM.

\section{E Ernst}

Complementary Medicine, Peninsula Medical School, Exeter, UK

E-mail: Edzard.Ernst@pms.ac.uk

\section{REFERENCES}

1 House of Lords Select Committe on Science and Technology. Complementary and Alternative Medicine. London: Stationery Office, 2000

2 Hentschel C. Profiling 'centres of excellence' in CAM research. Complement Ther Med 2002;10:46-8

\section{A one-handed method for obtaining arterial blood}

Reporting a high rate of needle-stick injuries, Mr Elmiyeh and his colleagues (July $2004 J R S M^{1}$ ) offer no detail on the techniques. I would not be surprised if arterial puncture was overrepresented. Here I describe a one-handed method that might lessen the hazard.

The most commonly used method to obtain arterial blood is to palpate for the pulse with fingers from one hand while inserting the needle with the other hand directly juxtaposed or under the fingers from the first hand. This carries risks of needle-sticks if an uncooperative or disoriented patient moves. Another established method is to insert the needle at an anatomical location where arterial pulsations are visible through the skin. This is one-handed, but in many patients it cannot be used because pulses are not visible transcutaneously. My one-handed method works as follows. (1) Palpate for the arterial pulse and mark the approximate location of the pulse with an indentation from the cap of the closed syringe. (2) Again locate the pulse by palpation and make a mental note of its relation (if there is any deviation) from the indented mark. (3) Clean the area with alcohol. (4) Insert the needle with one hand, using the mark as a guide. (5) If the blood is drawn with a safety needle, recap it with one hand.

\section{Eric Lewin Altschuler}

Mount Sinai School of Medicine, 1425 Madison Avenue, Box 1240,

New York NY, 10029, USA

E-mail: Eric.Altschuler@mssm.edu

\section{REFERENCE}

1 Elmiyeh B, Whitaker IS, James MJ, Chahal CAA, Galea A, Alshafi K. Needle-stick injuries in the National Health Service: a culture of silence. J R Soc Med 2004;97:326-7

\section{The sickly Stuarts}

Milo Keynes, in his diligent review of Professor Holmes' book (June $20004 J R S M^{1}$ ), implies that the contents as described by him contradict rather than confirm the premise of the title. History certainly suggests that the royal
Stewarts were a tough lot, prolific and often long-lived despite the dangerous, disease-ridden, wartorn times in which they lived, not to mention the unsavoury lifestyle of many of them.

King Robert II of Scotland, grandson of the Bruce, was the first monarch to hold the hereditary title of Steward. The bloodline ran unbroken from him through his son and then five descendants, all called James Stewart, and all fathering many children, in or out of royal wedlock. However the last of these, James V of Scotland died very shortly after the birth of his daughter Mary. So Mary Queen of Scots had no need in later life to marry her cousin Darnley in order to become a Stewart monarch — she was born one. She also died one, in her mid-forties, having endured imprisonment in a succession of damp and unhygienic castles over two decades until her execution. Sickly? Surely not.

'The six Stuart monarchs' described in Professor Holmes' book succeeded the first eight Stewart monarchs of Scotland as described above. As Milo Keynes reports, they were in turn outlived by the Old and Young Pretenders and the latter's brother the Cardinal; all three Jacobite Stewarts lived to a ripe old age (for the times) in exile abroad. And Sophia, Electress of Hanover, grand-daughter of James Stewart, VI and I, had initiated the Hanoverian succession which then followed and indeed occupies the British throne to this day.

A bloodline running from 1370 until the present time hardly makes the case for a strain of sickliness. Nor is a consistent pattern of hereditary disease apparent.

Therefore I agree with Milo Keynes' closing paragraph and was interested to read Graham Brack's thoughtful letter in the August JRSM. ${ }^{2}$ As he indicates, Holmes' spelling of the surname is incorrect; Mary Queen of Scots was brought up in France from babyhood and married the Dauphin as Marie Stuart. The spelling in this country was always Stewart - from King Robert II, the Steward.

Pamela Boxx

Alderdale, Carrbridge, Inverness-shire PH23 3AU, Scotland, UK

\section{REFERENCES}

1 Keynes M. The Sickly Stuarts [Book review]. J R Soc Med 2004;97:306-7 2 Brack G. The Sickly Stewarts [Letter]. J R Soc Med 2004;97:412

In his review of The Sickly Stuarts ${ }^{1}$ Milo Keynes states, concerning James VI \& I, that 'his weak legs remain unexplained'. I would draw attention to a paper in which I offered the diagnosis of cerebral palsy as the basis of the descriptions (by Sir Anthony Weldon and other contemporary observers) of James's appearance, along with the 
evidence of the royal portraits. ${ }^{2}$ The diagnosis has been commended by a number of medical and historian colleagues-Lockyer, for instance, in his 1998 biography ${ }^{3}$ - and the only doubter I have met queried the possibility that James, who loved hunting, could have suffered from such a disability. I was inspired to remind him of the success of Riding for the Disabled and he was forthwith persuaded.

It does seem that the subject of the Stuarts merits closer attention. In particular, the heirs of the historians who have derided James for four centuries have yet to assess his career in the light of the disability I have documented.

\section{A W Beasley}

37 Hay Street, Oriental Bay, Wellington, New Zealand

\section{REFERENCES}

1 Keynes M. The Sickly Stuarts [Book Review]. J R Soc Med 2004;97: 306-7

2 Beasley AW. The disability of James VI \& I. Seventeenth Century 1995;10:151-62

3 Lockyer R. James VI \& I. London/New York: Longman, 1998: 200

\section{Art about hospitals}

The artists who have depicted events in hospital go back well before Lowry and Hepworth (mentioned in the letter of Nigel Cooke ${ }^{1}$ ). Visitors to the Royal Academy's Vuillard Exhibition earlier this year may have seen The Surgeons, a large painting featuring the surgeon Dr Antonin Gossett and the anaesthetist Dr Bourreau.

Though not unique this is an uncommon subject for great painters. The lavish catalogue informs me that Toulouse Lautrec painted An Operation by Dr Péan at the Hôpital International 1891 and Munch The Operation 1902. Vuillard's painting is dated 1912-14 but was reworked in 1925 and 1937. A photograph of the scene by Guy Cogeval has different arrangement and shows the face of Dr Jean Berger (back to the artist in the painting).

I was curious about the identity of Dr Bourreau and contacted Professor Jean Lassner. He told me Dr Maurice Bourreau was the first physician anaesthetist in Paris at the end of the 19th century. His son Jacques followed him in working with Professor Gossett and died recently aged 96.

\section{A Padfield}

351 Fulwood Road, Sheffield S10 3BQ, UK

E-mail: a.padfield@sheffield.ac.uk

\section{REFERENCE}

\section{Medication errors and confusion over labelling}

Dr Wheeler and his colleagues (August $2004 J R S M^{1}$ ) make a strong case for standardized labelling to avoid confusion over ratios and percentages in drug solutions. May we draw attention to another potential source of confusion in relation to drug labelling. The unlabelled ampoule in Figure 1, which we presume to have contained Betnesol (betamethasone), was taken out of its packaging during

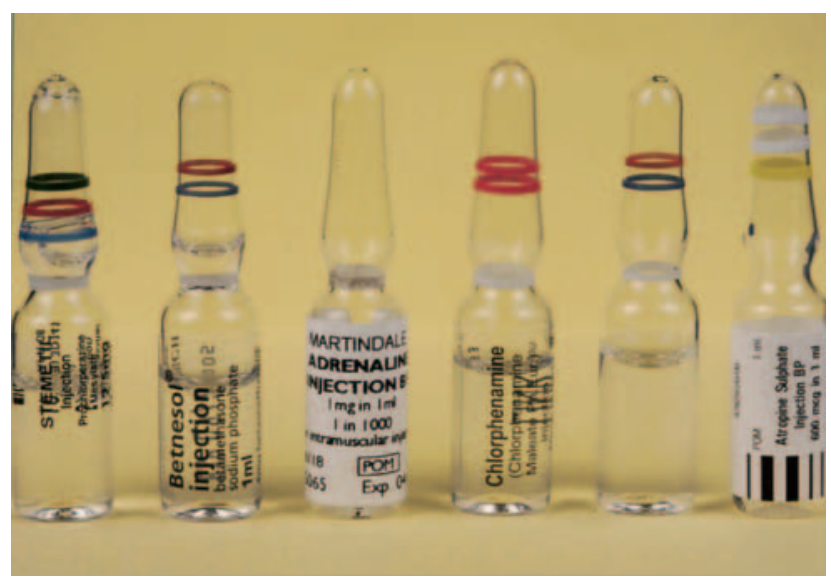

Figure 1 An assortment of ampoules, including one accidentally unlabelled. Colour version available on [www.jrsm.org]

routine cataract surgery for planned periocular injection. Theatre staff reacted appropriately by discarding it, and we reported the incident to the Medicines and Healthcare products Regulatory Agency. We also advised the manufacturers. The absence of a label was due to a manufacturing error, fortunately not coupled with the loss of coloured bands which do help to distinguish it from other products. However, this picture illustrates another potent source of error. Even when intravenous medications are correctly labelled, the similarity between their appearances is an example of a latent or potential systems failure.

\section{Roxane J Hillier}

Simon P Kelly

Royal Bolton Hospital, Bolton BL4 OJR, UK

\section{REFERENCE}

1 Wheeler DW, Remoundas DD, Whittlestone KD, et al. Doctors' confusion over ratios and percentages in drug solutions: the case for standard labelling. J R Soc Med 2004;97:380-3

\section{Personality disorder and somatization}

Professor Tyrer's classification of personality disorder into $\mathrm{R}$ (treatment-resisting) and S (treatment-seeking) types (August $2004 J R S M^{1}$ ) has utility outside psychiatryparticularly in primary care, where people frequently consult with somatization disorder and simultaneously partake of complementary therapies elsewhere. ${ }^{2}$ 
Dimensional ratings may be more reliable than categorical ones, but most general practitioners will be able to recognize the $\mathrm{R}$ and $\mathrm{S}$ groupings in somatizers, the former anxious to change their environment, and the latter themselves.

When it comes to interventions it may be that, as in psychotherapy, ${ }^{3}$ doctor/patient factors are as important as the type of therapy used. If a somatizing tendency is a relatively fixed part of personality, people with $\mathrm{R}(\mathrm{S})$ and $\mathrm{S}(\mathrm{S})$ should select their primary care physicians with care. Perhaps their first and most important task is whether to choose a 'splitter' or a 'lumper'.

\section{Malcolm McCoubrie}

St George's Hospital Medical School, London SW17 ORE, UK

E-mail: mccoubri@sghms.ac.uk

\section{REFERENCES}

1 Tyrer P. New approaches to the diagnosis of psychopathy and personality disorder. J R Soc Med 2004;97:371-4

2 Ernst E, White AR. The BBC survey of complementary medicine use in the UK. Complement Ther Med 2000;8:32-6

3 Beutler LE, Machado PP, Neufelt SA. Therapist variables. In: Bergin AR, Garfield SL, eds. Handbook of Psychotherapy and Behaviour Change. New York: Wiley, 2004

\section{Kikuchi's disease}

In their case report of a patient with Kikuchi's disease Dr Chung and colleagues (July $2004 J R S M^{1}$ ) refer to reported associations with systemic lupus erythematosus, Hashimoto's thyroiditis and infection with toxoplasmosis, Yersinia enterocolitica and herpesvirus 6. Kikuchi's disease has also been associated with four other autoimmune diseasespolymyositis, ${ }^{2}$ mixed connective tissue disease, ${ }^{3}$ adult and juvenile onset Still's disease ${ }^{4}$ and the antiphospholipid syndrome. ${ }^{5}$ In addition cases have been linked with breast and gastric malignancy ${ }^{6,7}$ and infections with Epstein-Barr virus, parvovirus B19 and herpesvirus $8 .{ }^{8-10}$

As Chung et al. state, a viral aetiology has been suggested but never satisfactorily proven. Given the variety of disease associations, it is possible that Kikuchi's disease represents an unusual response of histiocytes and T-cells to a range of local or systemic immune stimuli, including both foreign and self antigens.

\section{Benjamin Rhodes}

\section{Ali S M Jawad}

Department of Rheumatology, Royal London Hospital, London E1 4DG, UK E-mail: alismjawad1@hotmail.com

\section{REFERENCES}

1 Chung TT, Chowdhury N, Piper K, Chowdhury TA. Pyrexia and lymphadenopathy in a south Asian woman. J R Soc Med 2004;97:336-8

2 Wilkinson CE, Nichol F. Kikuchi-Fujimoto disease associated with polymyositis. Rheumatology 2000;39:1302-4
3 Aqel NM, Amr SS, Najjar MM, Henry K. Kikuchi's lymphadenitis developing in a patient with mixed connective tissue disease and Hashimoto's thyroiditis. Br J Rheumatol 1997;36:1236-8

4 Ohta A, Matsumoto M, Ohta T, et al. Still's disease associated with necrotizing lymphadenitis (Kikuchi's disease): reports of 3 cases. $J$ Rheumatol 1988;15:981-3

5 Papaiouannou G, Speletas M, Kalousi V, Pavtilou-Tsiontsi A. Histiocytic necrotizing lymphadenitis (Kikuchi-Fujimoto disease) associated with antiphospholipid syndrome: case report and literature review. Ann Haematol 2002;81:732

6 Aqel NM, Al-Sewan M, Collier DS. Kikuchi's disease in axillary lymph nodes draining breast carcinoma. Histopathology 2000;36:280-1

7 Radhi JM, Shinnider L, McFadden A. Kikuchi's lymphadenitis and carcinoma of the stomach. J Clin Pathol 1997;50:530-1

8 Yen A, Fearneyhough P, Raimer SS, Hudnall SD. EBV-associated Kikuchi's histiocytic necrotizing lymphadenitis with cutaneous manifestations. J Am Acad Dermatol 1997;36:342-6

9 Yufu Y, Matsumoto M, Miyamura T, Nishimura J, Nawata H, Oshima K. Parvovirus B 19-associated haemophagocytic syndrome with lymphadenopathy resembling histiocytic necrotizing lymphadenitis (Kikuchi's disease). Br J Haematol 1997;96:868-71

10 Huh J, Kang GH, Gong G, Kim SS, Ro JY, Kim CW. Kaposi's sarcoma-associated herpesvirus in Kikuchi's disease. Hum Pathol 1998; 29:1091-6

\section{The death of Napoleon}

It was with fascination that I read the paper 'Channelling the Emperor: what really killed Napoleon?'(August 2004 $\left.J R S M^{1}\right)$, but I must emphasize that despite its title it is only concerned with the immediate cause of Napoleon's death. As indicated in my 1996 paper on Napoleon's health, ${ }^{2}$ the Emperor first complained of nausea and upper abdominal discomfort after food in July 1820. The dyspepsia worsened to give loss of appetite, constant nausea, frequent vomiting, upper abdominal pain and constipation. There were periods of remission but the pain and vomiting became increasingly insistent. He lost weight and by the end of January 1821 could only manage fluid nourishment, finally taking to his bed on 17 March. On 27 April he vomited blood and his condition deteriorated with further bleeding and lapses into unconsciousness before death on 5 May.

At necropsy in front of sixteen observers including seven British doctors, of whom five signed the official report, the external surface of the stomach appeared healthy. On opening, however, it contained altered blood and almost its entire lining was cancerous: a scirrhous cancer had converted the stomach into a leather-bottle stomach with spread to the adjacent lymph nodes and with a perforation that had become sealed off. There was a family history of gastric carcinoma, and Napoleon realized he was dying of the same disease as his father and grandfather, remarking on 15 April, 'I know the truth and I am resigned'.

Clinically the cause of death was clearly gastric carcinoma, but on the publication of my paper in 1996, I 
received abusive letters with accusations that Napoleon had died from deliberate arsenical poisoning. This theory had received encouragement in 1961 when some, though not all, samples of his hair were found to contain abnormal amounts of arsenic. Arsenic was used in medicaments such as Fowler's and Donovan's solutions, and liquor arsenicalis was still in use as a general tonic and for loss of appetite when I qualified. The drawing room at Longwood House in St Helena was redecorated in 1819 , but a specimen of the wallpaper applied at that time contained only low levels of arsenic when analysed in 1982.

As the immediate cause of death from, say, carcinoma of the prostate may be cardiac failure, so the immediate cause of Napoleon's death has now been explained to those who still believe he died from arsenic toxicity and not from a carcinoma of the stomach.

\section{Milo Keynes}

3 Brunswick Walk, Cambridge CB5 8DH, UK

\section{REFERENCES}

1 Mari F, Bertol E, Fineschi V, Karch SB. Channelling the Emperor: what really killed Napoleon? J R Soc Med 2004;97:397-9

2 Keynes M. The medical health of Napoleon Bonaparte. J Med Biog 1996;4:108-17

\section{The history of St Mary's}

I was pleased to see John Ballantyne's review of my history of St Mary's Hospital (August $2004 J R S M^{1}$ ). I would, however, like to correct one remark, where he questions my assertion that the 1988 merger with Imperial College achieved 'minimal change with maximum protection'. My point was rather different. I suggest that, at least initially, the merger 'seemed to have achieved minimal change with maximum protection'. But the paragraph continues, though the change seemed nominal, in fact 'St Mary's had relinquished real power to Imperial College. If it were to change its mind about leaving St Mary's be, the school would find it difficult to resist. This was precisely what happened during the 1990s. With another change of rector, with new political pressures given focus by Sir Bernard Tomlinson's shake-up of the hospitals, and not least, with a change of opinion at St Mary's itself, the school did lose its name, its dean, and more besides'.

\section{E A Heaman}

History Department, McGill University,

855 Sherbrooke St West, Montreal QC H3A 2T7, Canada

\section{REFERENCE}

1 Ballantyne J. St Mary's: the History of a London Teaching Hospital [Book Review]. J R Soc Med 2004;97:405-6 